\title{
KARAKTERISASI HETEROGENITAS RESERVOIR LAPANGAN X DENGAN DYNAMIC LORENZ COEFFICIENT
}

\author{
CHARACTERIZING RESERVOIR HETEROGENEITY OF FIELD X \\ WITH DYNAMIC LORENZ COEFFICIENT
}

\author{
IRA HERAWATI \\ Jurusan Teknik Perminyakan Fakultas Teknik Universitas Islam Riau \\ Jalan Kaharuddin Nasution 113 Pekanbaru 28284 \\ iraherawati.amrul@yahoo.com
}

\begin{abstract}
Abstrak
Pada proses injeksi air (secondary recovery) dimana air berfungsi mendorong minyak ke sumur produksi, distribusi air akan dipengaruhi oleh sifat heterogenitas suatu reservoir. Distribusi pendesakan air sulit untuk dideteksi karena air cenderung untuk mengalir di zona-zona yang berpermeabilitas tinggi. Oleh karena itu dalam rangka pengukuran heterogenitas reservoir pada tahap injeksi air, penting untuk mempertimbangkan pengaruh geometri aliran yang disebabkan oleh sifat dinamika batuan. Studi ini bertujuan untuk melakukan karakterisasi heterogenitas reservoir dengan injeksi air di Lapangan X. Proses pengukuran derajat heterogenitas menggunakan metode Lorenz coefficient dinamis (dynamic Lorenz coefficient) yang merupakan pengembangan dari parameter Lorenz coefficient. Sifat dinamis injeksi air yang meliputi geometri aliran injeksi dianalisis dengan menggunakan streamline. Informasi yang didapat dari simulasi streamline berupa laju alir injeksi dan time of flight (TOF) streamline akan menjadi dasar perhitungan volume pori yang tersapu oleh air injeksi. Sehingga nilai flow capacity dan storage capacity $(\mathrm{F}-\Phi)$ untuk masing-masing region dapat dihitung. Selanjutnya derajat heterogenitas reservoir dihitung dengan persamaan Lorenz.
\end{abstract}

Kata kunci : Heterogenitas, Lorenz coefficient dinamis, steramline, flow capacity-storage capacity $(\mathrm{F}-\Phi)$

\begin{abstract}
In water injection processes, where water displaces oil, the resulting water distribution depends on the heterogeneity of the reservoir. However, it is often difficult to establish the water distribution although the water tends to flow through the higher-permeability layers. The resulting water distribution indeed relates to the rockrelated dynamic behavior of water. Thus, during water injection, the reservoir rock heterogeneity measures and the effects of flow geometry consideration to water distribution are very important. This thesis is aimed to characterize the reservoir heterogeneity of Field $\mathrm{X}$ under water injection. The heterogeneity measures were determined using dynamic Lorenz coefficient, an extended parameter of the previously known Lorenz coefficient. The dynamic behavior of water including its flow geometry was analyzed using streamlines properties.The information obtained from the streamline simulator including injection flow rates and time of flight (TOF) of the streamlines was used to calculate the pore volumes swept by the injected water. As a result, the flow capacity and storage capacity of the region studied could be determined. The reservoir heterogeneity measures were then calculated by applying Lorenz's equation.
\end{abstract}

Key words: heterogeneity, Dynamic Lorenz coefficient, streamlines, flow capacity-storage capacity $(\mathrm{F}-\Phi)$

\section{PENDAHULUAN}

Heterogenitas reservoir didefinisikan sebagai variasi sifat-sifat reservoir dalam dimensi ruang. Idealnya, jika reservoir bersifat homogen, maka pengukuran sifat reservoir di setiap 
lokasi akan terdeskripsi dengan tepat. Tetapi hampir tidak ada satu reservoir pun yang berkelakuan seperti itu. Sebaliknya sifat heterogenitas hampir selalu terdapat pada semua reservoir .

Pada pinsipnya heterogenitas suatu reservoir memiliki pengaruh terhadap kinerja reservoir. Untuk itu pengukuran tingkat heterogenitas suatu reservoir menjadi salah satu hal penting. Hal ini untuk membantu mempertimbangkan keputusan-keputusan yang akan diambil dalam proses perencanaan maupun pengembangan suatu lapangan minyak.

Shook (2005) $)^{19}$ mengembangkan perhitungan Lorenz coefficient untuk menentukan derajat heterogenitas reservoir yang mempertimbangkan sifat dinamis injeksi air. Konsep ini dikembangkan dengan menggunakan simulasi streamline untuk menentukan distribusi injeksi dan geometri aliran fluida. Simulasi streamline ini akan memberikan informasi laju volumetrik aliran dan time of flight (TOF) streamline. Dengan mengetahui distibusi aliran yang tersebar di sepanjang jalur-jalur yang dilaluinya, heterogenitas dihitung berdasarkan persamaan Lorenz coefficient. Parameter ini dikenal sebagai Lorenz coefficient dinamis (Dynamic Lorenz coefficient).

Dengan mengaplikasikan metode ini pada model reservoir yang dibangun atas dasar ketidakpastian data, diharapkan pengukuran heterogenitas reservoir menjadi lebih akurat. Sehingga memberikan manfaat yang baik dalam pengembangan lapangan dengan sistem injeksi air.

Tujuan dari penelitian ini adalah melakukan karakterisasi/pengukuran heterogenitas reservoir Lapangan-X yang mempertimbangkan sifat dinamis injeksi air dan perhitungan sweep efficiency di reservoir tersebut, dengan menggunakan parameter Lorenz coefficient dinamis. Penelitian ini dibatasi pada analisis pengaruh sifat dinamis reservoir dengan injeksi air pola lima titik terbalik dengan menggunakan software GOCAD dan simulator Frontsim.

\section{METODE PENELITIAN}

Metode yang dilakukan pada penelitian ini meliputi kegiatan terstruktur mulai dari melakukan studi literature, mempersiapkan data dan model reservoir, pembuatan pola-pola inverted five spot tiruan dan mengelompokan sumur injeksi dan sumur produksi, melakukan aplikasi metode dengan software GOCAD dan simulator Frontsim untuk mengetahui streamline, dan melakukan pemetaan Lorenz coefficient untuk melihat heterogenitas Lapangan X, untuk selanjutnya dilakukan analisis dan evaluasi hasil studi yang dilakukan.

\section{Lokasi Penelitian}


Lapangan X merupakan salah satu lapangan minyak yang termasuk dalam area yang dikelola oleh PT. Chevron Pacific Indonesia Distrik Minas. Lapangan X berlokasi sekitar 40 $\mathrm{km}$ sebelah barat dari lapangan minyak utama Minas atau kurang lebih $70 \mathrm{~km}$ sebelah barat laut kota Pekanbaru. Lapangan ini berada pada Cekungan Sumatera tengah yaitu pada Blok Rokan PSC dan sebagian kecil pada Blok Siak PSC.

\section{HASIL DAN PEMBAHASAN}

\section{Aplikasi Software GOCAD}

Proses penentuan Lorenz coefficient dinamis pada studi ini dilakukan dengan menggunakan aplikasi yang terdapat di dalam software GOCAD. Software GOCAD yang digunakan merupakan versi terbaru (2010) yang dilengkapi kemampuan untuk menetukan heterogenitas suatu reservoir. Dalam studi ini GOCAD digunakan untuk menetukan heterogenitas reservoir Lapangan X dengan metode Lorenz coefficient dinamis. Data untuk input workflow GOCAD dapat dilihat pada Tabel 1.

Tabel 1. Data untuk input workflow GOCAD

\begin{tabular}{|l|c|}
\hline & $1: 39$ \\
\hline Komplesi sumur produksi & $1: 39$ \\
\hline Komplesi sumur injeksi & $10000 \mathrm{bbl} /$ day \\
\hline Maksimum liquid di sumur produksi & $10000 \mathrm{bwi} / \mathrm{day}$ \\
\hline Maksimum air yang diinjeksikan & $500 \mathrm{psia}$ \\
\hline Minimum BHP sumur produksi & $1000 \mathrm{psia}$ \\
\hline Maksimum BHP sumur injeksi & $2000 \mathrm{ft}$ \\
\hline Referensi kedalaman & $800 \mathrm{psia}$ \\
\hline Referensi tekanan & $4747 \mathrm{ft}$ \\
\hline Oil Water Contac & $120 \mathrm{hari}$ \\
\hline Lama time step & 4 \\
\hline Jumlah time step & \\
\hline
\end{tabular}

\section{Penentuan Streamline dengan Simulator FrontSim}

Simulator yang digunakan untuk menentukan streamline dalam pelaksanaan studi ini adalah FrontSim. Simulator ini merupakan simulator reservoir multiguna. Dapat digunakan untuk menjalankan proses simulasi black-oil, maupun simulasi dengan tujuan khusus, seperti model reservoir 3D irreguler (tidak beraturan) dan kesalahan grid, compressibilitas, perubahan well control, dan gravity segregation seperti pada sumur multi komponen, 
multiphase flow. Properties reservoir yang diinputkan untuk menentukan streamline dengan simulator FrontSim dapat dilihat pada Tabel 2.

Tabel 2. Karakteristik dan propertis reservoir untuk simulasi streamline

\begin{tabular}{|c|c|c|}
\hline Properties & Nilai & Satuan \\
\hline Kedalaman reservoir & 2000 & $\overline{\mathrm{ft}}$ \\
\hline Gravity minyak & 0.865 & ${ }^{\circ} \mathrm{API}$ \\
\hline Tekanan reservoir & 800 & Psia \\
\hline Temperatur reservoir & 265 & ${ }^{\circ} \mathrm{F}$ \\
\hline Viskositas minyak pada $\mathrm{Pb}$ & 2.41 & $\mathrm{Cp}$ \\
\hline Kompresibilitas minyak & $0.387 \times 10^{-4}$ & $\mathrm{psi}^{-1}$ \\
\hline Viskositas air & 0.3 & $\mathrm{Cp}$ \\
\hline Kompresibilitas air & $0.36 \times 10^{-5}$ & $\operatorname{psia}^{-1}$ \\
\hline Densitas air & 0.937 & $\mathrm{gr} / \mathrm{cc}$ \\
\hline Compresibilitas batuan & $3.6 \times 10^{-6}$ & $\operatorname{psia}^{-1}$ \\
\hline $\begin{array}{l}\text { Faktor volume formasi } \\
\text { minyak pada } \mathrm{Pb}\end{array}$ & 1.1395 & $\mathrm{RB} / \mathrm{STB}$ \\
\hline Faktor volume formasi air & 1.035 & $\mathrm{RB} / \mathrm{STB}$ \\
\hline Oil water Contac & 4747 & $\mathrm{Ft}$ \\
\hline
\end{tabular}

Running FrontSim dilakukan dalam empat time step dengan mengatur waktu time step selama 120 hari. Hal ini dengan pertimbangan agar injeksi mempunyai waktu yang cukup dari kondisi transient menuju kondisi steady state. Setelah keempat time step terpenuhi maka run akan berhenti dan FrontSim menghasilkan output laju alir volumetrik dan time of flight (TOF). File yang dikeluarkan oleh FrontSim berupa file binnary streamline. file ini akan dikonversi oleh GOCAD dalam file ASCII sehingga dapat dibaca hasil keluarannya.

Informasi yang didapat dari file yang dikeluarkan oleh FrontSim akan memberikan gambaran geometri aliran di model reservoir yang diberikan, seperti terkihat pada gambar 1 . Gambar tersebut menunjukkan streamline aliran injeksi ke masing-masing sumur produksi di seluruh pseudo five spot pattern model reservoir. 


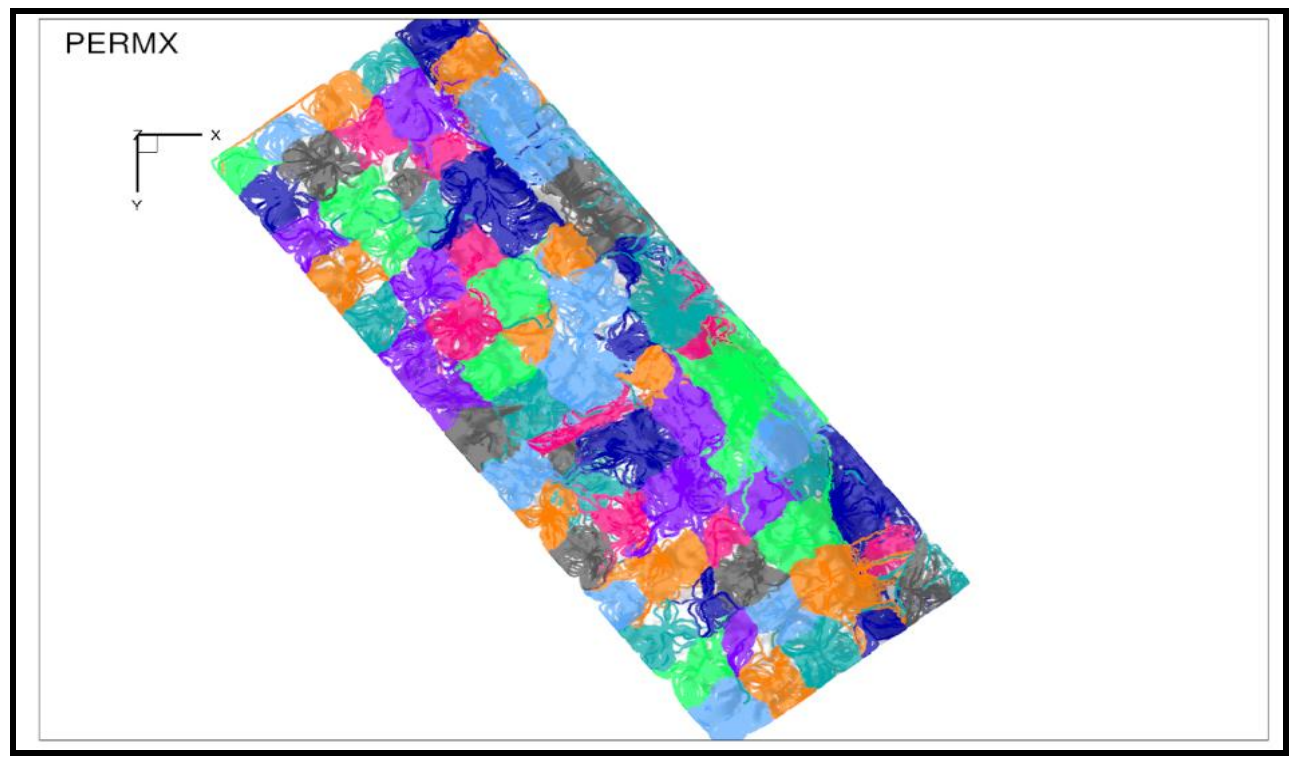

Gambar 1. Streamline aliran injeksi di model reservoir Lapangan X

TOF, panjang flowpath dan luas dari geometri aliran itu sendiri menjadi sesuatu yang diukur secara komprehensif. Setiap distribusi streamline merupakan fungsi waktu dan panjang streamline yang menggambarkan geometri aliran. Semakin panjang dan banyak streamline yang mengalir dari injeksi ke produksi semakin besar TOF yang dibutuhkan.

Dengan perhitungan ini maka diperoleh TOF untuk masing-masing streamline yang berasal dari masing-masing laju injeksi air $\left(\mathrm{q}_{\mathrm{i}}\right)$. Dengan mengetahui laju alir, $\mathrm{q}_{\mathrm{i}}$, dan TOF, $\tau_{\mathrm{i}}$, maka volume pori untuk masing-masing streamline, $\mathrm{Vp} \mathrm{p}_{\mathrm{i}}$, juga bisa dihitung.

\section{Alokasi Injeksi pada Sumur-Sumur Produksi}

Hasil simulasi streamline berupa informasi laju alir volumetrik dan TOF dari proses running FrontSim, akan dikonversi oleh GOCAD dalam bentuk file ASCII. Konversi ini akan menghasilkan data alokasi injeksi ke masing-masing produksi. Dalam proses GOCAD time step akan dilaporkan dalam 7 alokasi sampai proses berada pada kondisi steady state. Dan laporan alokasi yang digunakan untuk perhitungan Lorenz coefficient dinamis adalah alokasi step ke tujuh. Laporan alokasi ini berguna untuk melihat berapa laju alir masing-masing sumur injeksi dan volume pori yang dilalui streamline.

Dari hasil simulasi streamline yang diperoleh, diketahui bahwa total volume pori yang dikunjungi oleh streamline adalah $=1,50003 \times 10^{8} \mathrm{RB}$. Sedangkan total volume pori yang tidak dikunjungi oleh streamline adalah $=1,57835 \times 10^{8} \mathrm{RB}$. Total volume pori di model reservoir adalah $3,07377 \times 10^{8} \mathrm{RB}$. Jadi volume pori yang tidak dikunjungi oleh streamline adalah sebesar 50,69\%. Masing-masing streamline mempunyai TOF dan panjang streamline yang berbeda-berbeda. 


\section{Fraksi Alokasi Injeksi}

GOCAD juga mengeluarkan informasi fraksi alokasi injeksi. Harga ini merupakan fraksi dari alokasi injeksi untuk seluruh sumur produksi yang diinjeksi. Tabel Fraksi alokasi injeksi pada model reservoir dapat dilihat pada Tabel 3. Fraksi alokasi yang ditampilkan dalam tabel tersebut hanya untuk sebagian sumur injeksi saja. Nilai fraksi alokasi injeksi ini merupakan deskripsi dari persentase injeksi yang terdistribusi ke sumur-sumur produksi.

\section{Total Volume Pori Streamline (Vp) dan Laju Alir Injeksi (Q)}

Dari aplikasi metode menggunakan GOCAD diperoleh hasil perhitungan total Volume pori dan Laju injeksi yang dilewati oleh seluruh streamline, untuk masing-masing region yang diwakili oleh sumur-sumur injeksi (seperti terlihat pada Tabel 4). Perhitungan Vp total yang terdapat di Tabel 4 adalah volume pori streamline pada kondisi i $\left(\mathrm{Vp}_{\mathrm{i}}\right)$ yang merupakan fungsi dari laju alir volumetrik untuk streamline i $\left(\mathrm{q}_{\mathrm{i}}\right)$ dan time of flight, $\tau_{\mathrm{i}}$ pada kondisi i.

Dari sini dapat difahami bahwa volume pori yang diperoleh dari data keluaran GOCAD adalah total volume yang dilalui streamline dari satu sumur injeksi ke sumur-sumur produksi yang dituju. Semakin besar laju injeksi yang mengalir semakin banyak jumlah streamline yang dikeluarkan pada region tersebut. Secara umum semakin besar pula volume pori yang tersapu pada region tersebut. Masing-masing streamline memiliki flowpath dan TOF yang berbeda. Laju injeksi (Q) yang diperoleh dari analisis streamline oleh software GOCAD adalah representasi dari permeabilitas dengan geometri aliran yang dilalui oleh streamline.

Pada Tabel 4 juga terlihat fraksi volume pori yang tersapu terhadap volume pori total di masing-masing region ( $\mathrm{Vs} / \mathrm{Vp}$ ). Disini terlihat $\mathrm{Vs} / \mathrm{Vp}$ dihitung dalam waktu tak berdimensi (dimensionless time). Dalam hal ini GOCAD mencatat laporan volume pori injeksi pada saat dimensionless time berada pada kondisi satu volume pori injeksi (1PVI) dan dua volume pori injeksi (2PVI).

Tabel 3. Fraksi Vp total dan Q total streamline masing-masing region injeksi

\begin{tabular}{|c|c|c|c|}
\hline Sumur injeksi & Sumur produksi & Fraksi Vp & Fraksi Q \\
\hline INJ70 & PRD78 & 0.0585 & 0.0092 \\
\hline INJ70 & PRD83 & 0.0098 & 0.0066 \\
\hline INJ70 & PRD84 & 0.4363 & 0.3236 \\
\hline INJ70 & PRD90 & 0.4954 & 0.6606 \\
\hline INJ65 & PRD60 & 0.0225 & 0.0102 \\
\hline INJ65 & PRD66 & 0.0448 & 0.0061 \\
\hline INJ65 & PRD72 & 0.1879 & 0.0862 \\
\hline INJ65 & PRD77 & 0.0147 & 0.0222 \\
\hline INJ65 & PRD78 & 0.4728 & 0.4835 \\
\hline INJ65 & PRD83 & 0.0413 & 0.0403 \\
\hline INJ65 & PRD84 & 0.216 & 0.3515 \\
\hline
\end{tabular}




\begin{tabular}{|c|c|c|c|}
\hline INJ62 & PRD74 & 0.2446 & 0.2647 \\
\hline INJ62 & PRD75 & 0.3546 & 0.2625 \\
\hline INJ62 & PRD80 & 0.2175 & 0.2832 \\
\hline INJ62 & PRD81 & 0.1832 & 0.1896 \\
\hline INJ61 & PRD73 & 0.4014 & 0.3145 \\
\hline INJ61 & PRD74 & 0.1629 & 0.1225 \\
\hline INJ61 & PRD79 & 0.3805 & 0.5018 \\
\hline INJ61 & PRD80 & 0.0552 & 0.0612 \\
\hline INJ59 & PRD60 & 0.0032 & 0 \\
\hline INJ59 & PRD64 & 0.0773 & 0.0813 \\
\hline INJ59 & PRD65 & 0.0566 & 0.0218 \\
\hline INJ59 & PRD66 & 0.0099 & 0 \\
\hline INJ59 & PRD69 & 0.0597 & 0.025 \\
\hline INJ59 & PRD70 & 0.243 & 0.2581 \\
\hline INJ59 & PRD71 & 0.1132 & 0.1812 \\
\hline INJ59 & PRD72 & 0.1318 & 0.0246 \\
\hline INJ59 & PRD75 & 0.0011 & 0 \\
\hline INJ59 & PRD76 & 0.1946 & 0.2188 \\
\hline INJ59 & PRD77 & 0.0949 & 0.189 \\
\hline INJ59 & PRD78 & 0.0148 & 0.0003 \\
\hline INJ58 & PRD69 & 0.4367 & 0.5873 \\
\hline INJ58 & PRD70 & 0.0881 & 0.0789 \\
\hline INJ58 & PRD75 & 0.3696 & 0.2238 \\
\hline INJ58 & PRD76 & 0.1056 & 0.11 \\
\hline \multicolumn{4}{|l|}{$\tilde{\sim}$} \\
\hline INJ05 & PRD05 & 0.024 & 0.0502 \\
\hline INJ05 & PRD06 & 0.7073 & 0.6169 \\
\hline INJ05 & PRD12 & 0.2687 & 0.3329 \\
\hline
\end{tabular}

Tabel 4. Hasil perhitungan GOCAD untuk Q, jumlah streamline, Vp dan Vs/Vp

\begin{tabular}{|c|c|c|c|c|c|}
\hline Region & $\begin{array}{c}\text { Total laju alir } \\
\text { injeksi (Q), RB/hari }\end{array}$ & $\begin{array}{c}\text { Jumlah } \\
\text { Streamline }\end{array}$ & $\begin{array}{c}\text { Total volume pori } \\
\text { Streamline (Vp), RB }\end{array}$ & $\begin{array}{c}\text { Vs/Vp } \\
\text { @tD1 }\end{array}$ & $\begin{array}{c}\text { Vs/Vp } \\
\text { @tD2 }\end{array}$ \\
\hline INJ67 & 1720 & 1023 & $1.71 \mathrm{E}+06$ & 0.433 & 0.4847 \\
\hline INJ66 & 1289 & 737 & $1.13 \mathrm{E}+06$ & 0.3585 & 0.4061 \\
\hline INJ70 & 1402 & 696 & $2.53 \mathrm{E}+06$ & 0.4446 & 0.4958 \\
\hline INJ65 & 1563 & 1011 & $4.53 \mathrm{E}+06$ & 0.3984 & 0.4658 \\
\hline INJ62 & 1717 & 981 & $1.68 \mathrm{E}+06$ & 0.3886 & 0.4385 \\
\hline INJ64 & 855.7 & 484 & $1.02 \mathrm{E}+06$ & 0.4824 & 0.5444 \\
\hline INJ63 & 296.1 & 252 & $4.36 \mathrm{E}+05$ & 0.3838 & 0.4496 \\
\hline INJ61 & 575.2 & 388 & $8.35 \mathrm{E}+05$ & 0.4138 & 0.4832 \\
\hline INJ59 & 6745 & 2431 & $4.16 \mathrm{E}+06$ & 0.444 & 0.5141 \\
\hline INJ58 & 1003 & 512 & $8.95 \mathrm{E}+05$ & 0.4472 & 0.4965 \\
\hline INJ56 & 935.3 & 653 & $1.26 \mathrm{E}+06$ & 0.4166 & 0.4823 \\
\hline INJ60 & 619.6 & 404 & $2.30 \mathrm{E}+06$ & 0.4482 & 0.543 \\
\hline INJ57 & 473 & 321 & $7.24 \mathrm{E}+05$ & 0.4044 & 0.4855 \\
\hline INJ52 & 2741 & 964 & $1.59 \mathrm{E}+06$ & 0.455 & 0.5057 \\
\hline INJ53 & 7202 & 1806 & $2.16 \mathrm{E}+06$ & 0.5505 & 0.6093 \\
\hline INJ55 & 654.4 & 470 & $2.69 \mathrm{E}+06$ & 0.409 & 0.4823 \\
\hline INJ54 & 197.4 & 206 & $5.07 \mathrm{E}+05$ & 0.4216 & 0.5117 \\
\hline INJ51 & 784.8 & 546 & $1.04 \mathrm{E}+06$ & 0.4165 & 0.4892 \\
\hline
\end{tabular}




\begin{tabular}{|c|c|c|c|c|c|}
\hline INJ50 & 1232 & 610 & $3.18 \mathrm{E}+06$ & 0.4255 & 0.492 \\
\hline INJ49 & 1569 & 886 & $1.40 \mathrm{E}+06$ & 0.4811 & 0.5186 \\
\hline INJ48 & 7550 & 2145 & $2.69 \mathrm{E}+06$ & 0.4982 & 0.5733 \\
\hline INJ44 & 1989 & 931 & $1.92 \mathrm{E}+06$ & 0.4497 & 0.5128 \\
\hline INJ46 & 663.9 & 423 & $9.19 \mathrm{E}+05$ & 0.4483 & 0.501 \\
\hline INJ47 & 3580 & 1368 & $1.68 \mathrm{E}+06$ & 0.4829 & 0.5258 \\
\hline INJ45 & 234.2 & 239 & $1.14 \mathrm{E}+06$ & 0.4154 & 0.5297 \\
\hline INJ40 & 9008 & 2464 & $5.32 \mathrm{E}+06$ & 0.4294 & 0.5077 \\
\hline INJ43 & 2190 & 828 & $1.15 \mathrm{E}+06$ & 0.499 & 0.541 \\
\hline INJ38 & 4990 & 2090 & $4.58 \mathrm{E}+06$ & 0.4611 & 0.5128 \\
\hline INJ42 & $1.43 \mathrm{E}+04$ & 2529 & $1.74 \mathrm{E}+06$ & 0.4421 & 0.5658 \\
\hline INJ41 & 2815 & 904 & $1.08 \mathrm{E}+06$ & 0.438 & 0.4826 \\
\hline INJ35 & 2875 & 883 & $2.27 \mathrm{E}+06$ & 0.4387 & 0.5149 \\
\hline INJ36 & 5402 & 1615 & $2.67 \mathrm{E}+06$ & 0.4892 & 0.5537 \\
\hline INJ39 & 927.3 & 445 & $1.03 \mathrm{E}+06$ & 0.4704 & 0.5153 \\
\hline INJ37 & 4512 & 1006 & $1.19 \mathrm{E}+06$ & 0.4114 & 0.5252 \\
\hline INJ30 & $2.32 \mathrm{E}+04$ & 5016 & $8.82 \mathrm{E}+06$ & 0.4252 & 0.4892 \\
\hline INJ34 & 3157 & 861 & $1.38 \mathrm{E}+06$ & 0.5494 & 0.6108 \\
\hline INJ31 & 1240 & 625 & $1.45 \mathrm{E}+06$ & 0.4426 & 0.5284 \\
\hline INJ29 & $1.62 \mathrm{E}+04$ & 2865 & $3.72 \mathrm{E}+06$ & 0.5351 & 0.6512 \\
\hline INJ33 & 454.4 & 266 & $7.02 \mathrm{E}+05$ & 0.4457 & 0.5169 \\
\hline INJ28 & 4076 & 1701 & $3.47 \mathrm{E}+06$ & 0.4898 & 0.5303 \\
\hline
\end{tabular}

\section{F - $\Phi$ dan Efisiensi Penyapuan Volumetrik}

Penentuan F- $\Phi$ merupakan salah satu tujuan utama dari aplikasi metode dilakukan. Dengan mengetahui F- $\Phi$ yang diperoleh dari analisis streamline menggunakan software GOCAD, maka Lorenz coefficient dinamis dapat ditentukan. Dari data F- $\Phi$ yang diperoleh untuk masing-masing region injeksi, perhitungan Lc dapat dilakukan.

GOCAD juga menghasilkan nilai sejarah efisiensi penyapuan volumetrik untuk masing-masing region yang diwakili oleh satu sumur injeksi. Perhitungan efisiensi penyapuan volumetrik dapat diperoleh langsung dari harga F- $\Phi$ yang telah diketahui. Dengan menggunakan data tersebut efisiensi penyapuan volumetrik dapat dihitung.

Untuk setiap Tabel $\mathrm{F}-\Phi$ dan efisiensi penyapuan volumetrik yang ditampilkan dalam keluaran GOCAD merupakan harga $\mathrm{F}-\Phi$ dan efisiensi penyapuan volumetrik masing-masing region injeksi. Tabel 5 menunjukkan nilai $\mathrm{F}-\Phi$ dan efisiensi penyapuan untuk INJ02. 
Tabel 5. Nilai F - $\Phi$ dan Efisiensi penyapuan untuk INJ02

\begin{tabular}{|c|c|c|c|}
\hline PHI $(\boldsymbol{\Phi})$ & F (flow Capacity) & Dimension Less Time(t) $)$ & Sweep Efisiensi \\
\hline 0 & 0 & 0 & 0 \\
\hline 0.0007 & 0.0089 & 0.0821 & 0.0817 \\
\hline 0.0122 & 0.1153 & 0.1327 & 0.129 \\
\hline 0.0272 & 0.2193 & 0.1548 & 0.1474 \\
\hline 0.0454 & 0.3249 & 0.1829 & 0.168 \\
\hline 0.0659 & 0.4303 & 0.2033 & 0.1808 \\
\hline 0.088 & 0.5285 & 0.2517 & 0.2056 \\
\hline 0.115 & 0.6263 & 0.2942 & 0.2237 \\
\hline 0.1409 & 0.707 & 0.3464 & 0.2409 \\
\hline 0.1824 & 0.8106 & 0.4367 & 0.2633 \\
\hline 0.2083 & 0.8596 & 0.6487 & 0.2972 \\
\hline 0.2304 & 0.8876 & 0.8678 & 0.3256 \\
\hline 0.2636 & 0.9213 & 1.2189 & 0.3566 \\
\hline 0.2902 & 0.9371 & 1.8788 & 0.4049 \\
\hline 0.3137 & 0.9481 & 2.3325 & 0.4311 \\
\hline 0.3428 & 0.9592 & 2.9596 & 0.4594 \\
\hline 0.5173 & 0.9889 & 12.2345 & 0.6481 \\
\hline 0.5298 & 0.9898 & 13.3747 & 0.6604 \\
\hline 0.5432 & 0.9907 & 15.9134 & 0.6856 \\
\hline 0.5615 & 0.9918 & 16.9061 & 0.6942 \\
\hline 0.5729 & 0.9925 & 18.5535 & 0.707 \\
\hline 0.5909 & 0.9934 & 21.8541 & 0.7301 \\
\hline 0.6034 & 0.9939 & 23.5231 & 0.7405 \\
\hline & & & \\
\hline
\end{tabular}

Dalam aplikasi GOCAD, F- $\Phi$ dihitung berdasarkan geometri aliran yang digambarkan oleh streamline. Setiap streamline yang berasal dari suatu sumur injeksi mempunyai panjang dan waktu yang beragam. Misalnya pada INJ02 jumlah streamline yang tercatat oleh GOCAD adalah 591 streamline. Ini artinya pada 39 lapisan reservoir dalam model reservoir yang dianalisis terjadi 591 aliran ke sumur-sumur produksi yang dilaluinya (PRD08, PRD07,PRD01, PRD02).

Perhitungan Lorenz coefficient dapat dilakukan menggunakan plot F- $\Phi$ (seperti terlihat pada gambar 2. Untuk satu region (misalnya INJ02) diperoleh nilai Lc $=0,78$ yang merupakan representasi dari luas area kurva F- $\Phi$ (area ABCA) dibagi dengan luas area dibawah garis $45^{\circ}$ (area ADCA). Luas area ABCA untuk masing-masing region injeksi dapat dihitung dengan persamaan :

$$
\text { Luas area } \mathrm{ABCA}=\int_{0}^{1} \mathrm{~F} \cdot \mathrm{d} \Phi-0.5
$$

Dengan menggunakan persamaan di atas diperoleh luas area ABCA masing-masing region, yakni INJ02 $=0,40$, INJ04 $=0,39$ dan $\mathrm{INJ} 05=0,35$. Dari perhitungan ini terlihat bahwa semakin luas area kurva F- $\Phi$, semakin besar nilai Lc dan semakin heterogen suatu reservoir. Sejarah efisiensi penyapuan volumetrik untuk masing-masing region injeksi dapat 
ditentukan langsung dari data hasil perhitungan F- $\Phi$ seperti terlihat pada Tabel 5. Dari tabel tersebut dapat dibuat kurva sejarah efisiensi penyapuan terhadap waktu tak berdimensi.

Gambar 3 menunjukkan sejarah efisiensi penyapuan pada region INJ02 (Lc $=0,78$ ), INJ04 $(\mathrm{Lc}=0,76)$ dan INJ05 $(\mathrm{Lc}=0,69)$. Pada gambar tersebut terlihat bahwa pada region yang memiliki nilai Lc lebih tinggi (INJ02), efisiensi penyapuan membutuhkan waktu yang lebih lama untuk dapat menyapu seluruh volume pori region.

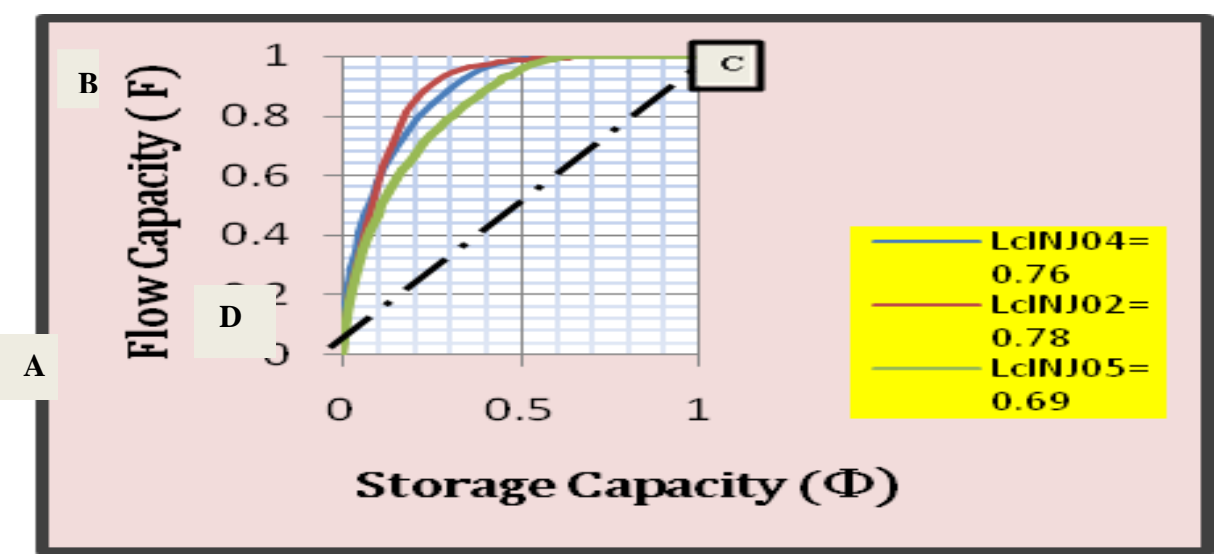

Gambar 2. Plot F- $\Phi$ ( Plot Lorenz Coefficient)

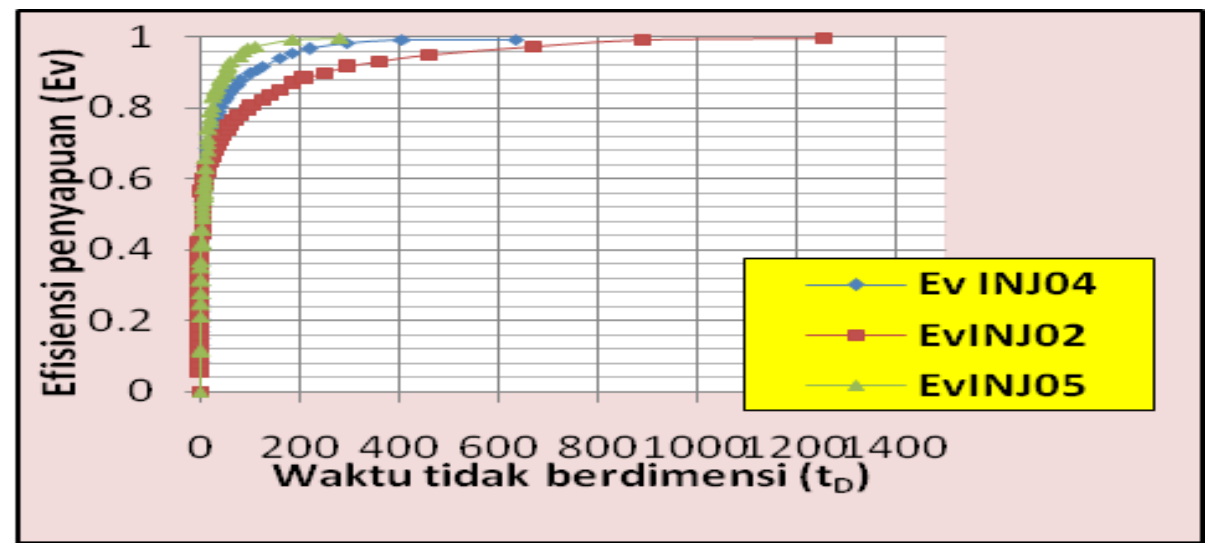

Gambar 3. Plot Efisiensi penyapuan terhadap waktu tak berdimensi ( $\left.t_{D}\right)$.

Gambar 4 dan 5 menunjukkan hubungan nilai Lc dinamis terhadap kemampuan injeksi untuk menyapu volume pori pada kondisi yang berbeda. Pada gambar tersebut telihat korelasi yang cukup signifikan antara nilai Lc dinamis terhadap fraksi $\mathrm{Vs} / \mathrm{Vp}$ (volume pori yang tersapu pada waktu tertentu dibanding volume pori total masing-masing region yang tersapu) pada saat dimensionless time. Semakin tinggi nilai Lc dinamis semakin rendah fraksi Vs/Vp. Pada kondisi injeksi satu volume pori (1PVI) nilai korelasi, $\mathrm{R}^{2}=0,872$. sedangkan pada kondisi injeksi dua volume pori (2PVI) nilai korelasi $\mathrm{R}^{2}=0,738$. 


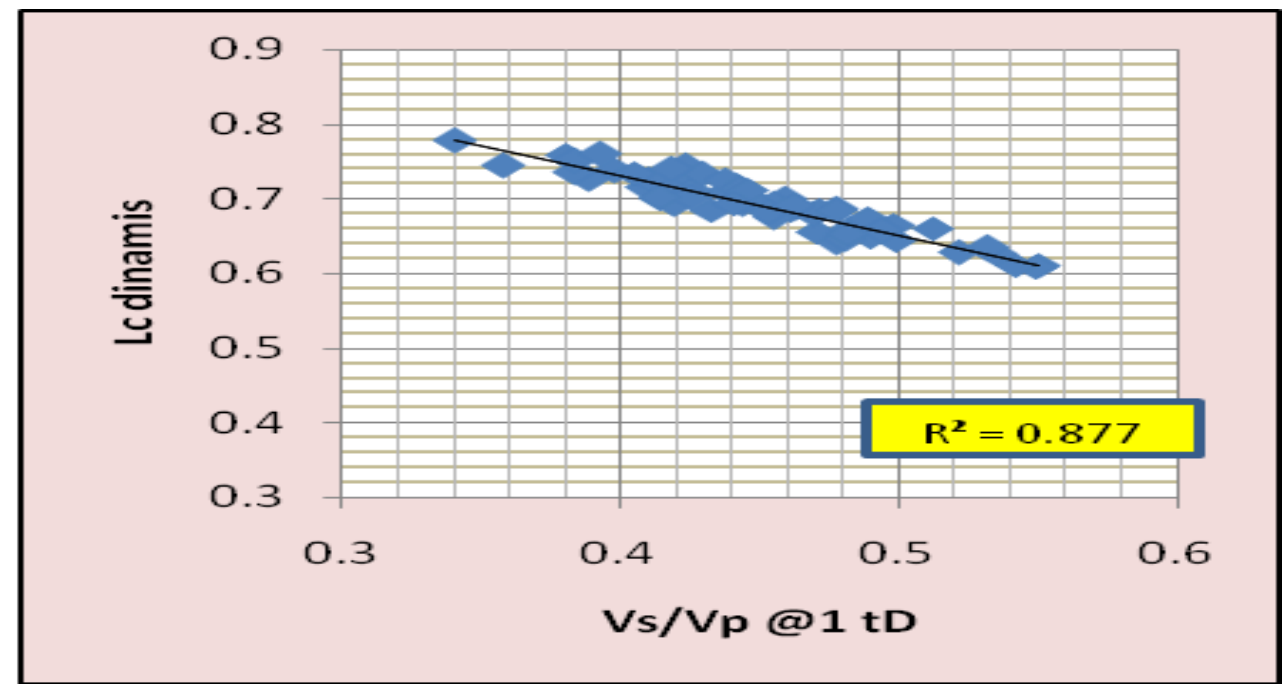

Gambar 4. Plot Lc dinamis terhadap Vs/Vp pada injeksi 1volume pori (1PVI)

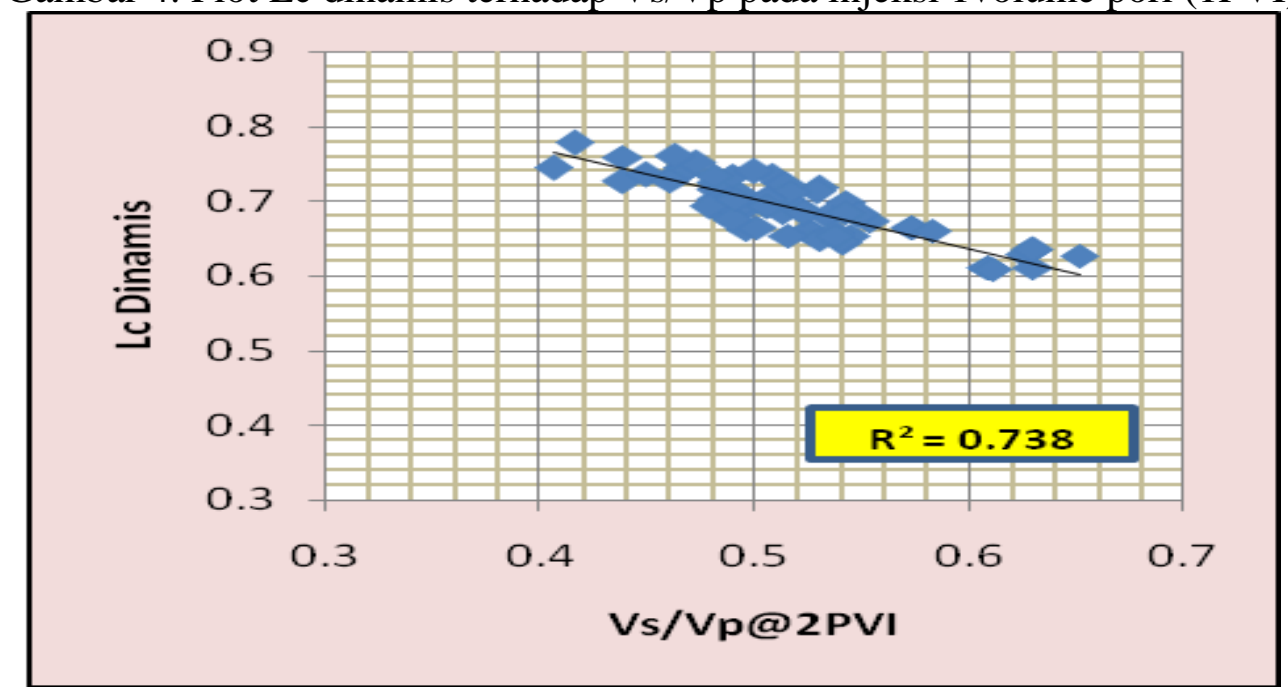

Gambar 5. Plot Lc dinamis terhadapVs/Vp pada injeksi 2 volume pori (2PVI)

Fakta ini juga memberikan alasan mengapa pengukuran derajat heterogenitas reservoir perlu dilakukan. Dengan mengetahui nilai Lc dinamis reservoir dapat membantu dalam penempatan sumur-sumur injeksi. Dimana semakin kecil harga Lc dinamis semakin baik efisiensi penyapuannya dan semakin besar fraksi volume penyapuannya. Hal ini tentunya juga diimbangi dengan pertimbangan-pertimbangan lainnya.

\section{Hubungan Jumlah Streamline, Laju Alir Injeksi Total (Q) dan Total Volume Pori yang} Tersapu (Vp)

Total volume pori yang tersapu oleh streamline adalah fungsi dari laju injeksi total dan TOF masing-masing streamline. Semakin tinggi laju alir injeksi maka akan semakin banyak jumlah streamline yang terdistribusi. Korelasinya dapat dilihat pada Gambar 6, dengan nilai $\mathrm{R}^{2}=0,913$. pada Gambar 7 juga terlihat korelasi yang cukup signifikan antara jumlah streamline terhadap total volume pori yang tersapu oleh streamline, dengan nilai $\mathrm{R}^{2}=0,875$. 
Hubungan antara total volume pori streamline $(\mathrm{Vp})$ terhadap laju alir injeksi total $(\mathrm{Q})$ masing-masing region dapat dilihat pada gambar 8. Dari Gambar tersebut telihat bahwa Vp dan $\mathrm{Q}$ tidak berkorelasi cukup baik, dengan nilai $\mathrm{R}^{2}=0,519$. Hal ini karena masing-masing streamline memiliki panjang dan TOF yang berbeda, sehingga pada perhitungannya peningkatan Vp tidak hanya dipengaruhi oleh meningkatnya laju alir injeksi saja, namun juga dipengaruhi oleh panjang flowpath dan TOF yang dibutuhkan oleh streamline untuk menyapu volume pori.

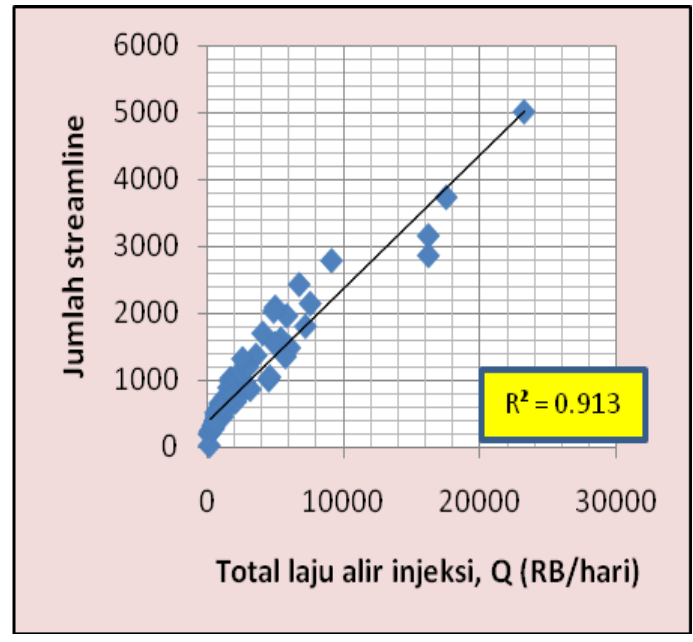

Gambar 6. Plot Laju alir injeksi total (Q) volume terhadap jumlah streamline.

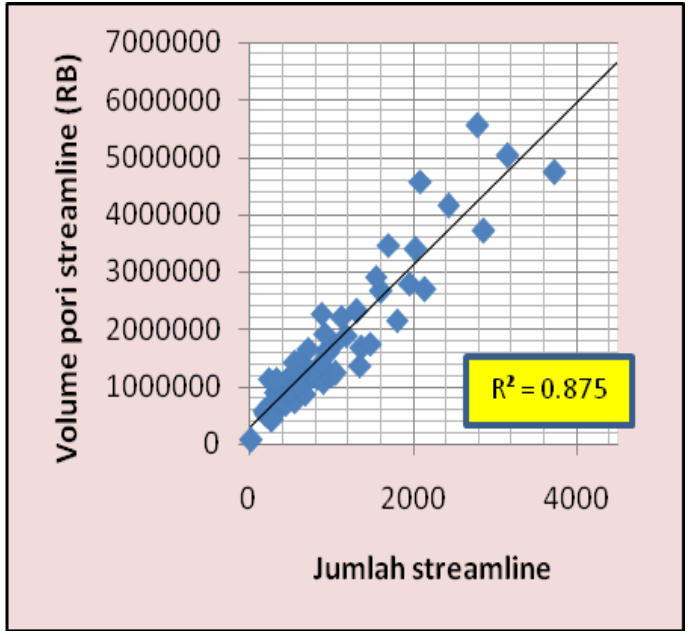

Gambar 7. Plot jumlah streamline terhadap pori streamline $(\mathrm{Vp})$.

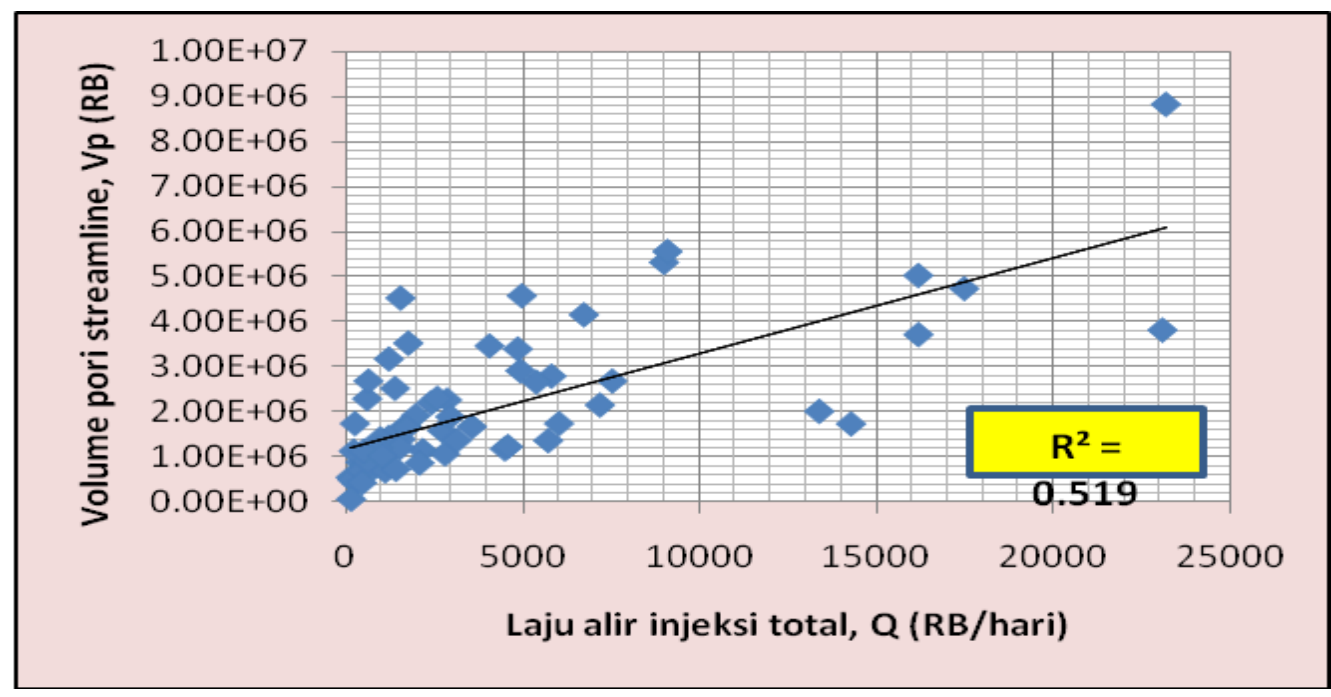

Gambar 8. Plot laju alir injeksi total (Q) terhadap volume pori streamline (Vp).

\section{Nilai Lorenz Coefficient Dinamis dan Heterogenitas Reservoir}

Nilai Lc dinamis yang diperoleh untuk satu sumur injeksi adalah nilai heterogenitas untuk satu geometri aliran untuk satu pattern di sekitarnya. Jadi untuk 75 pseudo pattern akan 
menghasilkan 75 nilai Lc dinamis pada model reservoir yang diteliti. Setelah harga $F-\Phi$ untuk masing-masing sumur injeksi diperoleh, maka nilai Lorenz coefficient dinamis untuk seluruh sumur injeksi dapat ditentukan.

Karakterisasi dilakukan dengan mengukur derajat heterogenitas reservoir. Nilai Lc dinamis diperoleh dari pseudo inverted five spot pattern yang disebar di seluruh model reservoir. Dari proses yang telah diterangkan pada bab sebelumnya diperoleh nilai Lc dinamis masing-masing sumur injeksi. Satu sumur injeksi mewakili satu nilai Lc untuk satu pattern (satu geometri aliran). Masing-masing region merupakan representasi wilayah Lapangan X.

Dari Tabel 6 terlihat distribusi nilai Lc dinamis mulai dari nilai yang tertinggi sampai terendah berkisar 0,7774 - 0,6086. Semakin tinggi nilai Lc dinamis menunjukkan semakin heterogen reservoir tersebut. Nilai-nilai ini dijadikan acauan untuk membuat peta Lc dinamis model Reservoir X dengan proses krigging. Peta Lc dinamis merupakan gambaran distribusi derajat heterogenitas reservoir di Lapangan X.

Tabel 6. Rangking heterogenitas pseudo pattern di model reservoir

\begin{tabular}{|c|c|c|c|c|c|}
\hline Region & Lc dinamis & Region & Lc dinamis & Region & Lc dinamis \\
\hline INJ02 & 0.7774 & INJ22 & 0.7277 & INJ56 & 0.7024 \\
\hline INJ04 & 0.7603 & INJ62 & 0.7259 & INJ16 & 0.7021 \\
\hline INJ71 & 0.7588 & INJ54 & 0.7248 & INJ59 & 0.7013 \\
\hline INJ37 & 0.7562 & INJ41 & 0.7246 & INJ61 & 0.7009 \\
\hline INJ11 & 0.7505 & INJ25 & 0.7225 & INJ72 & 0.6996 \\
\hline INJ66 & 0.7449 & INJ35 & 0.7218 & INJ60 & 0.6989 \\
\hline INJ75 & 0.7444 & INJ42 & 0.7188 & INJ70 & 0.6986 \\
\hline INJ17 & 0.7397 & INJ45 & 0.7174 & INJ58 & 0.6631 \\
\hline INJ65 & 0.7376 & INJ55 & 0.7155 & INJ13 & 0.6601 \\
\hline INJ63 & 0.7348 & INJ31 & 0.7128 & INJ47 & 0.6598 \\
\hline INJ01 & 0.7341 & INJ33 & 0.7122 & INJ18 & 0.6577 \\
\hline INJ30 & 0.734 & INJ50 & 0.7117 & INJ39 & 0.6555 \\
\hline INJ40 & 0.733 & INJ73 & 0.7095 & & \\
\hline INJ15 & 0.7321 & INJ51 & 0.7042 & & \\
\hline INJ08 & 0.7284 & INJ10 & 0.7028 & & \\
\hline
\end{tabular}

Gambar 9 menunjukkan peta distribusi Lc dinamis di model reservoir yang dilengkapi dengan seluruh sumur produksi dan sumur injeksi aktual yang terdapat di Lapangan X. Gradasi warna mulai dari yang terkecil sampai yang terbesar digambarkan dengan warna merah muda - oranye. Path warna hitam menggambarkan sumur-sumur produksi dan path warna merah untuk sumur-sumur injeksi. Pada peta ini terlihat bahwa sumur-sumur produksi dan injeksi menumpuk di daerah struktur puncak (top structur) reservoir. Dan distribusi nilai Lc yang relatif rendah juga terdapat di daerah top struktur ini. 


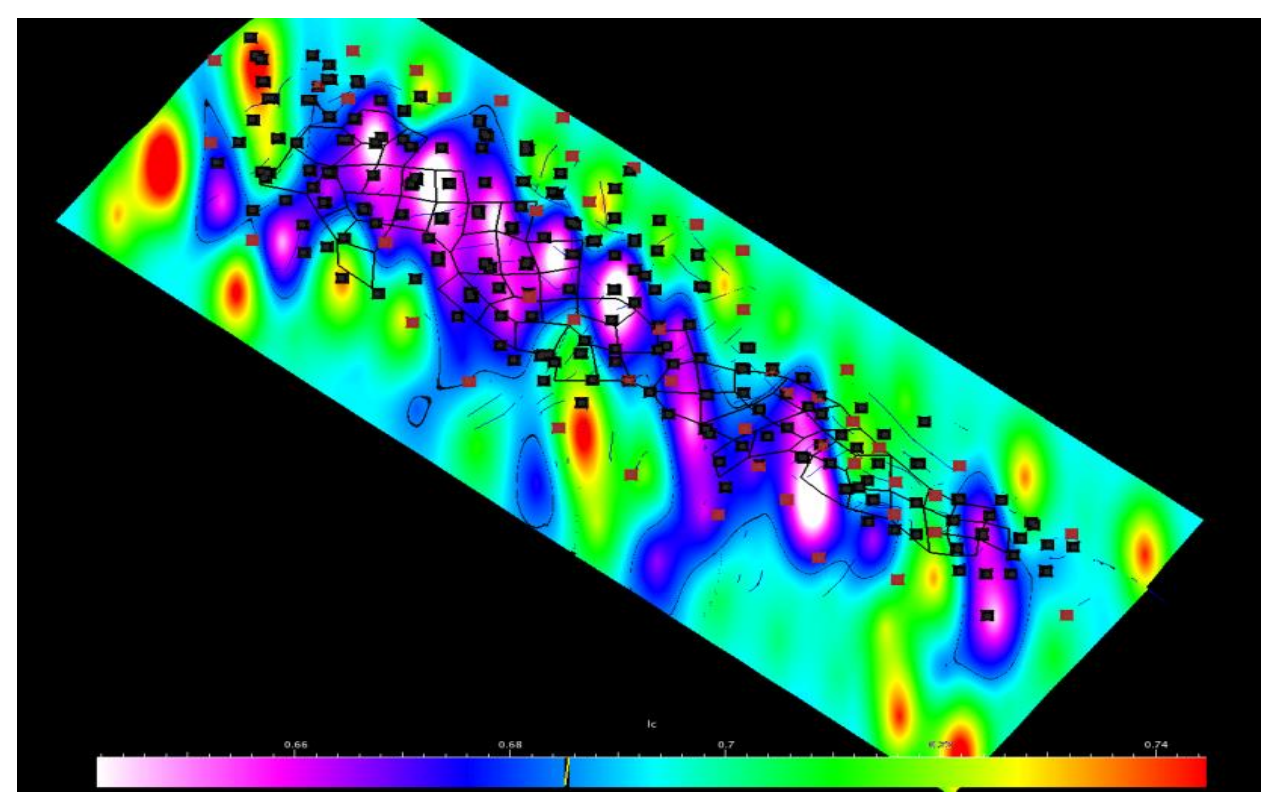

Gambar 9. Peta distribusi Lc dinamis pada model resrvoir X.

\section{KESIMPULAN}

Berdasarkan hasil penelitian yang penulis lakukan dapat disimpulkan sebagai berikut:

1. Dari hasil pengukuran Lorenz coefficient dinamis diketahui bahwa derajat heterogenitas reservoir di Lapangan X berkisar 0,60 - 0,78, dengan distribusi Lc yang relatif rendah terdapat di daerah top struktur reservoir.

2. Kurva sejarah efisiensi penyapuan volumetrik yang diwakili oleh region INJ02, INJ04 dan INJ05, menunjukkan bahwa semakin tinggi derajat heterogenitas reservoir, semakin rendah efisiensi penyapuan volumetrik injeksi air.

3. Dari perhitungan menggunakan analisis streamline dan kurva $F-\Phi$ didapatkan efisiensi penyapuan volumetrik rata-rata sebesar $45 \%$ pada kondisi satu volume pori injeksi (1PVI) dan 52\% pada kondisi dua volume pori injeksi (2PVI).

4. Perhitungan yang mempertimbangkan sifat dinamis injeksi air (Lc dinamis) dalam menentukan derajat heterogenitas suatu reservoir lebih realistis dilakukan karena menggambarkan kondisi reservoir sesungguhnya.

\section{DAFTAR PUSTAKA}

Balin, P.R., R. Solano, K.B. Hird and R.F. Volz, 2002, "New Reservoir Dynamic Connectivity Measurement for Efficient Well Placement Strategy Analysis Under Depletion," 2002, SPE paper 77375, presented at 2002 SPE Annual Technical Conference, San Antonio, Tx., 29 Sept - 2 Oct, 2002.

Craig, Forest F. Jr, 1971, “The Reservoir Engineering Aspects of Waterflooding”, Monograph Series, SPE Dallas, Texas, 63-66. 
Datta-Gupta, A. and M.J. King, 1995, "A semianalytic approach to tracer flow modeling in heterogeneous permeable media," Advances in Water Resources, 18 (1995) 9-24.

Deutsch, C.V. and S. Srinivasan, 1996, "Improved Reservoir Management Through Ranking Stochastic Reservoir Models," SPE paper 35411, presented at the 1996 SPE/DOE Tenth Symposium on Improved Oil Recovery, Tulsa OK, 21-24 April, 1996.

Hird, K.B. and O. Dubrule, 1998, "Quantification of Reservoir Connectivity for Reservoir Description Applications," SPE Reservoir Evaluation and Engineering, February, 1998, pp 12-17.

Idrobo, E.A., M.K. Choudhary, and A. Datta-Gupta, 2000, "Swept Volume Calculations and Ranking of Geostatistical Reservoir Models Using Streamline Simulation," SPE paper 62557, presented at the 2000 SPE/AAPG Western Regional Meeting, Long Beach, Ca.

Lake, L.W. 1989, “Reservoir Caracterization-2”, SPE Reprint Series No. 27.

Lake, L.W and Jensen, J.L, 1989, A Review of Heterogeneity Measure Used in Reservoir Characterization, presented at Journal SPE 20156.

Minas Field History and Data Field, PT. Chevron Pacific Indonesia, 2010.

Permadi, A. K. 2004, “Diktat Teknik Reservoir I-II” ITB : Bandung.

Saad, N., V. Maroongroge, and C.T. Kalkorney, 1996, "Ranking Geostatistical Models Using Tracer Production Data," SPE 35494 presented at the European 3-D Reservoir Modeling Conference, Stavanger, Norway, 16-17 April 1996.

Shook, G. M, and Forsmann, J. H, 2005, "Tracer Interpretation Using Temporal Moments on a Spreadsheet”, Idaho National Laboratory, Geothermal Technologies Program, Idaho.

Shook, G. M., and Mittchell K. M, 2009, "A Robust Measure of Heterogenity For Ranking Earth Models: The F-PHI Curve and Dynamic Lorenz Coefficient," SPE 124625, presented at the 2009 SPE Annual Thecnical Conference and Exhibition held in New Orleans, Lousiana, USA, 4-7 October 2009.

Shook, G. M., 2010, “Assessing Model Heterogeneity using Streamline Analysis” - A description of the method and implementation of fphi_Jan10. 